\title{
Taxonomic Government: Ecuador's National Herbarium and the Institution of Biodiversity, 1986-1996
}

\author{
Peter Taber \\ School of Anthropology, University of Arizona, USA / ptaber@email.arizona.edu
}

\begin{abstract}
From the late 1980s to the mid-1990s, biodiversity went from being an arcane, technical way of thinking about natural resources, to an important object of political concern and planning in Ecuador. This historically novel relationship to biological resources was catalyzed in large part by Ecuador's National Herbarium. The Herbarium's work modified existing regimes for managing plant resources during a time of economic crisis, and served as infrastructure for the field of biodiversity conservation in the country by helping to prioritize geographic regions for intervention. Biologists' practices were woven across protected area planning, environmental assessment and development projects. Through archival documentation and oral histories, I analyze biodiversity's emergence as a governable object out of an institutional arrangement I term "taxonomic government", organized around taxonomicallybased biological systematics.
\end{abstract}

Keywords: infrastructure, economization of biodiversity, governmentality

\section{Introduction}

Beginning in 1988, a field program administered by St. Louis-based Missouri Botanical Garden (MOBOT), under the auspices of the Ecuadorian state, conducted a number of formally contracted botanical inventories for foreign oil companies. The majority of the work took place in or around Yasuní National Park, the country's largest Amazonian protected area. Field technicians for the program that would become Ecuador's National Herbarium worked as fast as they could "behind the chainsaws and ahead of the bulldozers", as reports from the time put it (Neill, 1990). Technicians salvaged plant specimens from what had previously been the canopy level of felled trees before the sites were cleared for construction. Concluding a report to the Calgary-based oil company Petro-Canada on fieldwork along the company's newly constructed road, the MOBOTaffiliated botanist David Neill (1990) wrote:

Besides petroleum itself, the forest resource is the most important economically in the region; and in the long term the forest is much more valuable even than petroleum. How will this development take place, and how can the forest be managed on a sustainable basis? For rational development to take place, it will be important to know, for example, where stands of high-quality timber occur [...] and how to predict where these occur. 
Three decades later, Yasuní National Park is once again in the midst of large-scale petroleum development (Acosta, 2010; Rival, 2010). Critics who are unequivocally opposed to it, as well as those who aspire to balance petroleum production with environmental concerns now focus their advocacy on the number and uniqueness of species to be found in the park. Thus, evaluating the "global conservation significance of Ecuador's Yasuní National Park", Bass et al. (2010: 3) write that "Distribution maps of amphibian, bird, mammal and vascular plant species across South America show that Yasuní occupies a unique biogeographic position where species richness of all four taxonomic groups reach diversity maxima".

Neill and his colleagues in the late 1980s framed their work as a first step toward rational forestry, which could commercialize particular tree species in a coordinated, sustainable way. In contrast, the concerns of experts and the public presently center on the impending loss of species in an area now conceived as one of the most biodiverse in the world (Bass et al., 2010; Finer et al., 2009). The syntheses of biological studies prompted by the controversy unequivocally demonstrate the biological importance of Yasuní. They also show the enormous effort made to catalog species and quantify diversity within the park; to propose these as intrinsically valuable in lieu of any direct utility to broader Ecuadorian society; and, more recently, to link them to other environmental problems like climate change. In the intervening decades, then, a novel object - biodiversity - has become a compelling focus of political action.

This article uses the history of Ecuador's National Herbarium to examine how the social, technical and political concern for biodiversity was instituted in the country. The National Herbarium played a catalyzing role in this process by generating a technological apparatus that straddled public and private institutions and assisted with targeting conservation areas by provisioning species-level botanical data. Its work formed the basis for new relationships to Ecuador's biological resources as its methods and scientific products became widely available managerial tools.

The core of my analysis focuses on the period between 1986 and 1996. In 1986, a field program was proposed by MOBOT that would allow inter- national NGOs to design conservation programs in Andean South America on the basis of specimenlevel biological data. In 1996, Ecuador's Ministry of the Environment was created with a mandate framed in terms of the governance of protected areas for biodiversity conservation, replacing pre-existing Ecuadorian institutions. In these eleven years, the practices of systematic biology, and botany in particular, formed the foundation for a pervasive new way of linking institutions to the environment. The period coincides with the coining of the term "biodiversity" (Wilson et al., 1988; Takacs, 1996) and its ascendance as a theme of specialized literature, multilateral agreements, bilateral funding and widespread public interest. The present case thus helps us to think about how, and with what consequences, biodiversity emerged as a political problem in Ecuador.

To understand these issues, this article draws together science and technology studies scholarship on "economization" and infrastructure with the "governmentality" approach to the study of modern institutional power associated with Michel Foucault (Burchell et al., 1991). As scholars of economization have argued with regard to calculative rational action generally, the capacity to evaluate biological resources is, in part, a function of the specific technological setting in which actors operate (Callon et al., 2007). In Ecuador in the 1990s, biologists focused their efforts on creating knowledge infrastructure to assist with identifying biodiversity conservation priorities. Their frequently ad hoc "infrastructure work" (Star \& Bowker, 2010) resulted in enduring mechanisms for the management of biological resources. Drawing on oral history, historical archives and secondary literature, I show how the uptake of this work produced biodiversity as a "knowable and administrable domain" (Rose et al., 2006: 86), on the foundation of taxonomicallybased biological systematics. ${ }^{1}$

In order to better distinguish what kind of program biodiversity conservation was upon its entrance in the 1980s, I begin my examination of empirical materials by distinguishing two distinct paradigms by which plants were configured as resources in $20^{\text {th }}$ century Ecuador. I then turn to the creation of the National Herbarium, examining the infrastructural arrangements that 
made it possible to presumptively attribute value to territory in terms of biological resources, en masse. Following this, I examine how the National Herbarium applied the logic of biodiversity to petroleum work sites as a novel spatial scale of floristic evaluation, and molded the industry of environmental consulting. Finally, I show how foreign debt and austerity created the conditions for the Ecuadorian state's uptake of this technology, which spanned the fields of conservation and environmental consulting. Biodiversity became an institutionalized relationship to biotic resources as biologists' practices and infrastructures linked a wide range of public and private organizations. I conclude by briefly considering some contemporary implications of what I term "taxonomic government". First, I consider in greater detail how literature on economization, infrastructure and governmentality can inform our understanding of biodiversity.

\section{Instituting Biodiversity: Economization, Infrastructure, Government}

Ecuador's National Herbarium, and the organizations that it worked with, sought to reframe the diversity of life as a resource, a project of what Çalişkan and Callon $(2009,2010)$ refer to as "economization". Biologists conducted basic exploration and research in biological systematics, and used the resulting data for territorial planning. Their work revolved around the construction of new scientific infrastructures to coordinate between different organizations and communities of experts (Star \& Bowker 2010; Star 2010), with the eventual goal of reworking the existing Ecuadorian institutions involved in managing biological resources. Biodiversity conservation was thus a project of what Michel Foucault (2007) referred to as "government" or the "conduct of conduct" (Burchell et al., 1991: 2), defining and grappling with the problem of biodiversity loss by reformatting institutional relationships to biological resources.

Biologists working in Ecuador in the latter half of the $20^{\text {th }}$ century were alarmed by the rapid conversion of forest to agricultural purposes that they observed. MOBOT field botanists Calaway Dodson and Alwyn Gentry (1991) documented a severe example of this over three decades of fieldwork in the western, coastal region of the country. At that time, they estimated that only $4 \%$ of the forest remained that had existed at the beginning of the $20^{\text {th }}$ century. Their experience suggested that numerous species extinctions had already occurred in the region. They estimated that the total conversion of forest on the coast would result in the loss of over 1200 more endemic vascular plant species. The authors argued that the region was being damaged by state policies encouraging irrational land use, and that conservation programs needed to be enacted on the basis of more thorough biological inventory. ${ }^{2}$

Dodson and Gentry's approach was consistent with how biologists and others increasingly posed the fragility and finitude of life's diversity as a problem in need of intervention under the heading "biodiversity" in the late 1980s (Wilson et al., 1988). Biological explorers and their precursors had always identified local resources and circulated them through entrepreneurial and administrative networks (Müeller-Wille \& Scharf, 2009; Raffles, 2002; Sevilla \& Sevilla, 2013). What biologists called for with greater frequency in the 1980s was a different function that could presumptively treat the diversity of life en masse as a resource around which social relationships could be reorganized to avoid environmental devastation. Recent literature on economization thus provides a useful vocabulary with which to analyze how conservation "[enacted] particular versions of what it is to be 'economic"' (Callon et al., 2007: 4).

As suggested by Dodson and Gentry (1991), the central focus of conservation planning was on what, following Callon et al. (2002), we could call the "qualification" of plant resources through biological inventory. Callon et al. (2002) use the term "qualification" to characterize how new commercial goods are configured by interactions among various entities and processes such as advertising, testing, focus groups, and patterns of consumption. The salient properties of a product, the aspects that demand refinement by producers and form a value for consumers, emerge out of this distributed activity. "Qualified" objects may be framed as "singular" and incommensurable 
with other objects; ordinally ranked amidst other goods; or treated as stores of quantifiable value. International and domestic Ecuadorian actors qualified geographic areas of interest for biodiversity conservation in a variety of ways throughout the 1990s. These ranged from assertions about the scientific importance of sites due to the fact that they had never been biologically explored; to simple species lists; to the identification of endangered and endemic species; and eventually to diversity metrics generated through rigorous inventory. Conservation planning involved producing large quantities of "first-order" data (typically, lists of species found in a locale) that could then be summarized into new "secondorder" products (such as estimates of local endemism or floristic maps).

Biologists' practices treated the volume of living forms as a "value" distributed across geographic space (Bowker, 2005). While this is an intuitive simplifying formal move, the technical work required to produce descriptions of biodiversity in these terms is still massive (Bowker, 2000a). For example, botanists had long relied on spatially coarse records of plant collecting localities and the circulation of anecdotal information through networks of colleagues. Coordinating efforts to save biodiversity in Andean South America required $M O B O T$ to format and pool large volumes of spatially-referenced botanical data with information from other disciplines. These needed to be available to the various actors working on conservation, which then needed standardized ways to assess the information at hand. Economizing Ecuador's biodiversity was thus, among other things, a problem of knowledge-infrastructural design.

The National Herbarium comprised part of what I term a "technology of spatial prioritization" that grew up around biologists and other experts, spanned public and private organizations, and assisted with the identification of conservation targets. This technology enrolled the traditional tools of plant systematics into new projects of the management of biological resources. As Li (2007) puts it, conserving biodiversity was a matter of "rendering technical", or formulating the problem of conserving life's diversity in terms amenable to botanists' expertise (cf. Rose, 1999; Mitchell,
2003). Biological inventory and the production of knowledge infrastructures embedded experts in a technological setting that allowed them to apply formal decision criteria to biodiversity conservation interventions on the basis of their own disciplinary techniques (Miller \& Rose, 1997; Callon \& Muniesa, 2005).

As the National Herbarium was forming, Ecuador was undergoing sweeping political and economic changes, due largely to its foreign debt. From the 1980s to the 1990s Ecuador slid from economic stability to currency collapse. Those two decades saw massive inflation, reductions in public spending, the removal of subsidies for domestic industries, and the stripping away of controls on foreign investment (Hey \& Klak, 1999; Jácome, 2004). Thus, the emerging technology of spatial prioritization was guided by the needs of international actors, who provided the only funding available during this period of austerity. Moreover, neoliberal reforms had important impacts on how botanical fieldwork interacted with petroleum development, the country's most important economic sector. Botanical collecting not only used petroleum development to conduct fieldwork, but transposed the logic of biodiversity to the oil field to study the impacts of development. Biologists' practices and infrastructures eventually reoriented the Ecuadorian state's governance of biological resources, not by direct coercion, but by provisioning it with a new technology for reckoning with space and resources that cut across the burgeoning fields of conservation and environmental consulting.

Ultimately, I suggest that biodiversity was produced through "taxonomic government", a retrospectively discernable apparatus that crystallized over the time period in question with the National Herbarium at its center. The starting point for Foucault's analysis of "governmentality" was that the conduct of conduct is not the sole purview of a monolithic state, but occurs in countless ways throughout society (Silverstein, 2015; Erazo, 2013; Asdal, 2008a; Rose et al., 2006). ${ }^{3}$ The analytical question of interest to studies of governmentality is how particular mechanisms and rationales for the "conduct of conduct" become widespread, conventionalized and institutionalized - sometimes to the extent that they 
become constitutive features of "the state", though this is not necessary (e.g. Donzelot, 1997; Power, 1999). This analytical move refuses to posit transhistorical functions of the state so that the question can be posed more pointedly of how particular rationales and mechanisms coalesce into intelligible, enduring paradigms of political power.

From this perspective, the botanical norms by which new plant species are described are just as potentially "governmental" as more familiar functions of the modern state: they order social action. The practices on which taxonomic government was based were those of biological systematics, as MOBOT director Peter Raven and the biologist-philosopher E. O. Wilson put it, "hitherto regarded as 'little science"' but "badly in need of growing large" (1992: 1099). In examining "taxonomic government" I focus on the practices of biologists as these cut across numerous different organizations and projects. The term "taxonomic government" distinguishes the political technology that emerged in Ecuador in this period from environmental politics in which ecology or other disciplines played more prominent roles in Ecuador and elsewhere (e.g. Lowe, 2006). It also distinguishes this technology from that which might develop where statistical or molecular methods form the basis for large-scale biological inventory, rather than the physical inspection and description of specimens. I thus intend to highlight a form of governmentality based on a very specific set of practices. Taxonomic government emerged as one way of doing biodiversity on the basis of taxonomic biological techniques as these became increasingly available: biologists' infrastructure work defined both what the problem was, and how that problem would be passed along to other communities of experts (Karasti et al., 2010; Bowker \& Star, 2000). The approach taken here thus examines the reflexivity or "performativity" of social institutions through the infrastructure work involved in constituting them (Rabinow, 2003; Bowker, 2000b; Mackenzie et al., 2008; Jasanoff, 2013).

Before turning to the details of the technology of spatial prioritization that was founded by the National Herbarium, it is useful to briefly distinguish prior forms of resource management from the spatially-oriented rationality that came to characterize biodiversity conservation.

\section{Substantive and Spatial Logics of Plant Resource-Making}

While biodiversity is commonly referred to as a "resource", the program enacted by the National Herbarium deserves to be distinguished from other relationships to plant resources. In this section I contrast two different tendencies in the economization of plants, which I term "substantive" and "spatial" logics of resource-making. ${ }^{4}$ The substantive logic focused on particular plant species that posed identifiable utilities to people, especially through economic improvement and commercialization. The treatment of plants as "substantive" resources most closely resembles what someone is likely to have in mind when they think of a resource: a good that meets specific human needs or wants. On the other hand, the spatial logic began with the geographic space to which plants were assigned as a resource category. This is a more abstract and formal way of reckoning with resources, and a precursor to how plant resources were increasingly framed in biodiversity conservation in the 1990s. To exemplify the substantive logic, I turn to the work done by MOBOT's program in the mid-1980s in Ecuador. For the spatial logic, I examine the planning conducted in the mid-1970s, forming the basis for Ecuador's system of protected areas and the National Herbarium's later work. Contrasting these two logics shows how the work of the National Herbarium segued from a more conventional program of exploration and plant resource development, to one that emphasized the spatial distribution of flora as a basis for institutional planning.

The substantive and spatial logics examined here are best conceived as tendencies intrinsic to natural resource governance throughout colonial and postcolonial history (on forestry see Grove, 1996; Tucker, 2011; Mathews, 2011). In Ecuador, a substantive logic of plant resource-making formed the basis for the industrial use of plants for much of the $20^{\text {th }}$ century, either in the context of programs for national economic development with assistance from the U.S. Department of Agriculture (Acosta-Solís, 1944) or in transnational business dominated by firms like United Fruit 
(Striffler, 2001). After World War II, Latin American countries frequently relied on U.S. capital and technical expertise to develop natural resources, including plants (McCook, 2002; on Ecuador see Cuvi, 2011). As late as the mid-1980s, the pattern of plant science in the service of U.S. assisted resource development still held sway, in programs like the one that inaugurated MOBOT's field program in Ecuador.

MOBOT's field collectors, such as Dodson and Gentry, had worked sporadically in Ecuador since the 1950s (Dodson \& Gentry, 1978). The permanent field program that eventually became the National Herbarium was initiated by a USAIDfunded project with the Ministry of Agriculture and Livestock beginning in 1984. The project's stated goal was "to strengthen the capacity of professional foresters and botanists in Ecuador to study and manage the Ecuadorian humid tropical forests by means of a dendrological and economic botany study of selected sites in the forest of the Amazon region of Ecuador". ${ }^{5}$ Its primary deliverable to USAID and its Ecuadorian partner institutions was to be an illustrated dendrological guide, "Plant Resources of Amazonian Ecuador". MOBOT's work was part of a larger project designed to help the Ministry of Agriculture and Livestock identify and begin researching commercially viable trees in the Amazon, a region that had not received extensive dendrological study previously (Neill, 1985).

Provisioning useful information on commercializable tree species required the ability to perform plant taxonomy in the country, and thus demanded access to a herbarium. A herbarium can be conceptualized as a reference library of plants, built up through the gradual accumulation of specimens identified by experts in taxonomic families. The fieldwork conducted by MOBOT personnel was intended to produce specimens from Amazonian trees, and generate the scientific infrastructure required for future commercial research. MOBOT personnel began in 1985 by establishing a regular collecting site in the upper Amazon. Specimens were brought back to a herbarium dedicated to forestry outside of Quito, and duplicates of these were circulated internationally to be identified. As taxonomic identifications were sent back to Ecuador, a "local" collection of expertly identified specimens accumulated. The resulting information was fed into the larger USAID-supported research on useful plant species to characterize the properties of their woods, optimal growing conditions, yields and other factors. The substantive logic of economizing plants thus involved the intensive technical development of woody plant species on the basis of biological exploration and research in plant systematics through globally distributed scientific networks. MOBOT's forestry program resembled others in a longer history of collaboration in Ecuadorian forestry reliant on U.S. sources for technical expertise and capital (Cuvi, 2009). ${ }^{6}$

A project conducted jointly by the U.N.'s Development Programme and Food and Agriculture Organization in 1976 exhibits a contrastive, spatially-oriented logic of resource-making in Ecuador (UNDP-FAO 1976). Occurring just a few years prior to MOBOT's collaboration with USAID described above, projects such as this set the stage for a major burst in protected area planning during the late 1980s. The project's goal was to support the creation of national parks in order "to maintain outstanding wild areas of the country for the sustained production of a flow of products and services that will contribute to the benefit of the population and national development, without diminishing the natural capital of these areas". Rubrics for designing the system were borrowed from the Food and Agriculture Organization (UNDP-FAO 1974) and U.S. National Park Service (USNPS 1974). The report's criteria were intended to be comparable within and across national contexts, and match up with the categories of U.N. funding mechanisms (such as its recently minted Man and the Biosphere Programme) in a manner that presaged the conservation boom of the 1990s (Fairhead \& Leach, 2003). The project's final report presents geographic regions ranked according to coarse descriptions of resources, amenities or judgments of their uniqueness.

Biologists consulting for the World Wildlife Federation (WWF) produced a follow-up report in 1978 focused specifically on the Yasuní River watershed, which ranked fifth on the original report's overall list and first among its recommended protected areas in the Amazon (Pearson et al., 1978). The WWF report did not present 
information on the economic uses of plants in the watershed, but argued for its value on the basis of the density of plants found there and the distinctiveness of the flora. The authors identified 405 species, suggesting the area might have 12 times that in reality (Pearson et al., 1978: 15). The 1978 report advocated "complete protection", and suggested boundaries for a reserve.

The 1976 U.N. report framed Ecuador's prospective national parks as repositories of "natural capital" in need of rationalization: they required protection in order to maintain viable stocks of resources. The authors presumed that plants in these regions constituted some form of resource requiring further qualification. As opposed to the U.N. study, the 1978 WWF report says nothing about the economic value of the Yasuní watershed to the region or Ecuador more broadly, but insists on its value in terms of the abundance of plants there and the consequent need to study it further (in essence, its value adhered in its scientific interest). The spatial logic of economizing plants in the 1970s was thus a matter of framing territories in terms of resources presumed to exist within them, and later elaborating this value through biological fieldwork.

Scholarship in political ecology has theorized territorialization, the formation of new geographic units, emphasizing either the extension of state control over space (Vandergeest \& Peluso, 1995), or the formation of new regimes of capitalist extraction of natural resources (Brogden \& Greenberg, 2003; Sheridan, 2007). The U.N. and WWF studies of the 1970s loosely combined both of these aspects. The studies extended state planning to previously outlying regions of the territorial nation-state (Sevilla Pérez, 2013), using tools provided by international actors to attribute economic value that later needed to be confirmed and elaborated. The initial assumption of the 1976 U.N. study was that the resources would be of use to a developing capitalist economy. The prioritization of areas for protection had a "performative" dimension (Mackenzie et al., 2008; Bowker, 2000b), inasmuch as presumptively designating them as valuable provoked further study and attributions of value with the assistance of multilateral financing. This two-step process was accelerated and refined in the conservation boom that the National Herbarium helped to initiate, as I discuss below.

As biologists drew attention to species loss in Ecuador in the 1980s, rendering biodiversity technical was clearly not a matter of imposing expertise onto a domain that had previously lacked expert intervention. It rather involved pivoting an existing apparatus, oriented at the time to the substantive economization of plants, toward the goals of the emerging field of biodiversity conservation, and the distribution of plants across national space. MOBOT's forestry work with the Ministry of Agriculture and Livestock participated in an older paradigm of resource-making, linked during the $20^{\text {th }}$ century to the U.S. Forest Service and state-managed commercial forestry. ${ }^{7}$ However, one of MOBOT's goals of participating in the USAID program was to initiate a field program in the country that could lay the foundation for what would later be biodiversity conservation. In the process, the role of biological research was increasingly reconfigured to feed into projects predicated on a spatial logic of economization.

\section{A Technology of Spatial Prioritization}

In the late 1980s, as public support for forestry began to disappear, MOBOT botanists ended their project with USAID and the forestry department and began conducting fieldwork as the country's National Herbarium. ${ }^{8}$ Here I examine two projects in particular that had the logic of spatial prioritization prominently built into them. In the first, the National Herbarium's work was aggregated with other data to form a central repository of spatiallyreferenced biological information for Ecuador. This project involved pooling what Power (2004) terms "first-order" data products from various biological sciences. In the second project, sites with high plant diversity throughout the country were characterized on the basis of the National Herbarium's floristics as well as first-hand observations to provide summaries of regional conservation issues. This was an example of "second-order" aggregations of species-level data (Power, 2004). In both cases, the Herbarium and the techniques of botanists bridged the roles historically played by biological exploration and territorial management, and produced a new technology for 
prioritizing spaces for conservation through infrastructure design (Star \& Bowker, 2010).

The National Herbarium's establishment in Ecuador was motivated by a joint project with The Nature Conservancy (TNC), a Washington D.C.-based environmental NGO. In the early 1980s, TNC was in contact with MOBOT botanist Alwyn Gentry, and communicated its desire for a computerized database that would allow identification of conservation priorities. As Gentry noted in a memorandum to Peter Raven, this database would optimally be scalable and linkable to others in order to assist broader conservation efforts in Andean South America. Gentry wrote: "[TNC personnel] very clearly want (and obviously need and should want) a specimen-based approach. What they need to know is where individual species are, not what species occur in a given country". 9 Conservation work would thus be informed by floristics derived from species-level data, irrespective of political boundaries. This required collecting and taxonomically identifying physical specimens, an obvious role for MOBOT.

TNC's work in Latin America at the time was focused on building national Conservation Data Centers, storehouses of spatially-referenced biological data. Where the work was successful it provided an unprecedented level of biological detail over large geographic areas. In the case of floristics, botanical rubrics were developed to distinguish species compositions in upper canopy, lower canopy and understory, allowing mapping at the national level of these distinct forest components (CDC, no date). Botanical data were fed to the Conservation Data Center from MOBOT's own in-house database, and later integrated into a digital geographic information system. Aggregated data could then serve a large number of purposes, from coordinating TNC's own regional efforts, to designing biologically meaningful national maps, a process that one planning document refers to as "ecoregionalization" (CDC, 1990)..$^{10}$

An example of the National Herbarium's second-order products is its contribution of "datasheets" for a casebook on Centres of Plant Diversity by the International Union for Conservation of Nature (IUCN) beginning in the late 1980s. ${ }^{11}$ The first goal of the IUCN program was to "identify which areas around the world, if conserved, would safeguard the greatest number of plant species". Inclusion criteria for sites were based on numbers of species (or estimates thereof) and levels of endemism. Datasheets for each region contained brief floristic characterizations, descriptions of known useful plants, an "economic assessment" outlining local relationships to natural resources, threats to biodiversity, conservation recommendations and a bibliography.

The National Herbarium's contributions to the IUCN project encapsulate the overall tendency in this period to synthesize scientific research with botanists' informal observations from the field into informationally rich instruments. For example, National Herbarium botanists made two expeditions in the early and mid-1990s to the Cordillera del Cóndor, a low-lying mountain range on the Amazon side of the Andes. The region had not been identified by the 1976 UN study as a conservation priority. The National Herbarium's work there identified the cordillera as a limestone outcrop similar to the Guyana shield, a geological formation occurring at the intersection of Venezuela, Brazil, and Guyana far to the north. This discovery offered a promising window onto the region's evolutionary history (Ulloa \& Neill, 2006). Similarly, the National Herbarium produced a datasheet for Yasuní National Park drawing on its observations of unanticipated floristic heterogeneity in the lower Ecuadorian Amazon. In these cases, the National Herbarium's botanists emphasized their importance on the basis of scientific debates in a planning tool for an international audience.

Thus, the production of first-order data like species lists generated new second-order aggregations of botanical data in terms of which planning and scientific research could be coordinated. These were combined, in turn, with expert judgments about the value of particular locales in light of scientific debates and local environmental threats (Cochoy, 2008). With this combination of contextually-informed judgment and formal knowledge, the National Herbarium bridged the functions of biological exploration and territorial management. The larger technology of spatial prioritization relied on the ability to rapidly incorporate these findings into planning. 
The National Herbarium and the Conservation Data Center created the sociotechnical conditions for formal decision-making by embedding experts within an apparatus that mapped geography on the basis of taxonomically identified specimens. The broader technology of spatial prioritization in which these organizations participated was thus a "qualifying distributed device" (after Callon \& Muniesa, 2005) in which both conservation priorities, and the terms in which these would be conceived, were negotiated between experts and organizations. The two distinct steps of the 1976 U.N. study and the 1978 report by the WWF were collapsed into a productive cycle of feedback between the basic goal of aggregating biological data and the conceptualization of new scales of environmental governance. The work of visiting sites, collecting specimens, circulating findings among colleagues and synthesizing them produced zones of intensive environmental interest prior to the consolidation of evidence or deliberative procedures (Neill et al., 1999; Schulenberg \& Awbrey, 1998). Biodiversity, a new way of describing and valuing Ecuadorian space, was enacted in the way taxonomically-based biological systematics formatted and linked conservation organizations.

\section{Qualifying the Biotic, Framing the "Site"}

Botanical fieldwork (first for the forestry project, and later as the National Herbarium) brought botanists into direct contact with petroleum field operations in the Ecuador's Amazon. The difficulties of plant collecting and the politics of petroleum development incentivized collaboration between botanists and petroleum field operations. As plant collectors encountered and made use of petroleum development, practices of spatial prioritization used by international and national conservation organizations were transposed to the oil field. One result of this convergence was that the petroleum development "site" was framed as a scale of floristic evaluation and comparison in the emerging field of environmental consulting. Examining the National Herbarium's specimen collecting in the country's Amazon shows how the practices of spatial qualification required by conservationists were re-contextualized as governmental tools beyond protected area planning.

The orientation of the initial MOBOT-USAID program in the mid-1980s toward Amazonian forestry posed problems not normally encountered in ad hoc botanical plant collecting. First, physical access to far-flung collecting sites was difficult due to limited infrastructure in the region. Second, the Amazonian canopy from which specimens were collected was anywhere from 25 to 50 meters overhead, requiring a slow and physically laborious process of climbing the trees to retrieve them. The petroleum industry assisted with both of these problems. Botanists approached a team of drilling subcontractors to informally arrange specimen collecting at their work sites once trees had been felled. David Neill recalls the National Herbarium's first encounter with them in 1986 or 1987 thus:

\footnotetext{
We were driving along the road to Coca and stopped where they were drilling a well, and I sort of explained to them that we were interested... in where they were cutting down trees, because then we don't have to climb them, we can get specimens from the trees, botanical specimens, much easier including the epiphytes, and the trees if they're in flower or fruit, etcetera. So we became sort of camp followers of the petroleum industry... That had been sort of my modus operandi in Nicaragua and elsewhere and... that's generally the way botanists in the tropics have worked. Interview, 3.14.14. ${ }^{12}$
}

Leading this wave of foreign oil development was Conoco, then a subsidiary of chemical company DuPont. The development proposals in the late 1980s were controversial due in part to their plans to operate within Yasuní National Park. Conoco eventually sought to collaborate with environmentally-minded scientists, encouraged by the highly public legacy of environmental degradation by Texaco. ${ }^{13}$ Conoco courted a wide range of environmental and social advocacy organizations, both international and domestic, with a long list of criticisms of the project. The company's agreement to hire environmental consultants was seemingly based on a desire to insulate itself from future litigation. ${ }^{14}$ In addition to dividing environmental NGOs in the country (Rival, 2011), 
the Conoco drilling controversy inaugurated the field of biological petroleum consulting. The National Herbarium's work was central to this, as its opportunistic collecting evolved into a formal arrangement with Conoco in 1988, followed by a string of contracts for other oil companies in the mid-1990s.

Petroleum consulting precipitated a significant spike in productivity for botanists. Renner (1993) estimated that the history of botanical collecting in Ecuador's Amazon had produced about 60,000 collections in 250 years. ${ }^{15}$ On a single project, the National Herbarium collected 5,000 specimens from 1991-93 and was averaging about 500 collections per month at the time of a contract renewal in 1994. ${ }^{16}$ Other petroleum projects also generated large numbers of specimens, and rapidly built up the Herbarium's floristic knowledge of Ecuador's lower Amazon.

With new first-hand experience of the lower Amazon and the aid of a specimen collection that was accruing with quasi-industrial efficiency, National Herbarium scientists were able to treat the oil field as a space of both biological exploration and evaluation. Biological inventory offered a preliminary means of what Callon (1998) refers to as "framing" economic externalities: inventory delineated a type of development "impact", and subjected it to the formal rationality of biodiversity conservation. The treatment of biological resources as a value unevenly distributed across space was consequently implemented at a finer spatial scale than that typical of conservation planning, through the massive infrastructural support of the petroleum industry. The spatial qualification of plant resources examined and differentiated between sites scattered throughout what had previously been treated by conservationists as a single biotic region (the lower Ecuadorian Amazon), describing space at the level of the petroleum development "site".

Natural history and biological field science have historically relied on infrastructural development to gain access to field sites (e.g. Kohler, 2006; Hayden, 2003). The history traced here is distinguished by the move from such opportunistic fieldwork to the careful coordination of botanists with oil companies to place them on the ground as forest was being cleared; and eventu- ally to the insertion of biologists at proposed work sites prior to construction in order to describe a site's "baseline" condition. ${ }^{17}$ On the basis of the site, for the first time in Ecuador floristic comparisons were regularly being made with reference to something "outside" of biological field science. The result was that botanical knowledge was used in the petroleum development process to anticipate, describe or mitigate the impacts of oil work in the emerging field of environmental consulting. Coupling together the qualifying capacities of biological systematics and petroleum development, the field of environmental consulting effectively took the formal logic of biodiversity to an extreme that was impossible in biodiversity conservation at the national level. The infrastructure of biological inventory in the oil field was thus in place when U.S.-based environmental consultancies arrived in the mid-1990s to work in the oil field. Inventory was immediately integrated into these companies' environmental assessment procedures, and became a standard feature of Ecuadorian environmental impact assessment as regulation was formalized by the state in the late 1990 s and early 2000s.

The National Herbarium's work in the Amazon is an important example of how the practices of field biology and biological systematics extended outwards from the technology of biodiversity conservation planning to form more broadly applicable governmental tools. Similar practices were used in development projects supported by bilateral agencies, contributing to a burgeoning field of environmental consulting. This episode of plant collecting shows the feedback relationship that existed between the acquisition of biological knowledge through exploration and the consolidation of biodiversity as a domain that could be subjected to governmental techniques.

\section{Taxonomic Government in Search of a State}

By the mid-1990s, as a consequence of the projects described above, the National Herbarium formed the core of a technology of spatial prioritization used for targeting international conservation efforts, assisting with national-level protected area planning, and employed in envi- 
ronmental consulting. A qualifying distributed device for attributing value to space in terms of biological resources was strung together with taxonomically-based biological systematics at its core. These practices were interwoven with bilateral aid agencies, domestic and international NGOs, scientific institutions, private environmental consultancies, and transnational and domestic petroleum companies. Here I examine a parallel trajectory whereby this political technology was incorporated into public institutions beyond the National Herbarium. As a consequence of the country's economic problems, the rationales and practices of biodiversity conservation were integrated into the state, culminating in the creation of the Ministry of the Environment in 1996.

As discussed above, Ecuador had longstanding programs of plant research and forestry, but these relied on foreign technical and financial support, such as that provided by MOBOT and USAID in the mid-1980s (Cuvi, 2011). In the 1990s, the limited public funding for research on plant resources at Ecuador's forestry institute was further eroded by austerity measures. David Neill recalls:

During the kick that everybody had for privatizing everything in the early nineties... [Ecuador's forestry institute] decided they didn't want to have research anymore. So they basically fired everybody and turned the whole place [the forestry research station outside of Quito] over to, part of it went to the police for an academy and part of it was this indigenous university... that would have been about ninety-two, three [...] So all those specimens were incorporated into the National Herbarium... so, yeah, we inherited, the library was sort of like dumped out on the street, out in the open one day. So we got a truck, scooped up all the books we could and brought them into [the National Herbarium]. Interview, 3.14.14

Neill's anecdote dramatically illustrates the way that Ecuadorian state institutions were being redirected and repurposed throughout this period (in this case, literally salvaged by being hauled away in a rented pickup). MOBOT's botanists were forced to move to the National Herbarium in 1991, an institution that existed in name only at that point, under the authority of the country's Museum of Natural Sciences.
In the climate of austerity, MOBOT's move away from the forestry program needed the aid of private organizations with foreign financing. This was made possible in 1989 when the WWF and TNC engineered a "debt-for-nature" swap, allowing institutions to purchase chunks of the country's foreign debt at an eventual 86\% discount. Debtfor-nature swaps involved purchasing foreign debt to build institutions for environmental protection within the debtor country (Sadler, 1990). МОВОТ contributed to the agreement and, beginning in 1991, botanists operating as the National Herbarium were funded through this mechanism. Ecuadorian sucres were purchased on request by the Ecuadorian environmental NGO Fundación Natura and disbursed to the National Herbarium. ${ }^{18}$

The debt crisis and resultant austerity thus had two interacting effects. First, they cut back more traditional domestic programs of research and product development such as USAID had initially proposed to MOBOT in the mid-1980s. Second, inflation made it economically feasible to generate the technology of spatial prioritization needed by biodiversity conservation. The longstanding, but highly malleable practices of taxonomic systematics and biological fieldwork were reoriented away from programs of resource development and into conservation. While the Ecuadorian state attempted to keep environmental regulation to a minimum to position itself for debt renegotiations (Hey \& Klak, 1999), petroleum companies took up biological techniques preemptively and a new way of governing Ecuadorian development emerged, initially outside of the state.

After leaving the forestry program, MOBOT's botanists no longer answered to the Ministry of Agriculture. For most of the 1990s, the National Herbarium was headed by a U.S. expatriate botanist, staffed primarily with Ecuadorian scientists, formally operated under the auspices of Ecuador's Museum of Natural Sciences, corresponded with MOBOT for steering its scientific efforts, and answered to the private Ecuadorian NGO Fundación Natura for budgetary purposes. ${ }^{19}$ The most consistent oversight the Herbarium faced was the permitting process required for exporting specimens, leaving it largely free to serve as infrastructural support for biodiver- 
sity conservation in whatever manner was most expedient. The messiness of this arrangement should indicate both the weakness of the Ecuadorian state under austerity in the 1990s, and the severe analytical limitations of focusing on the national affiliation of institutions, rather than on the rationales and practices they deployed in such a context.

When Ecuador applied for World Bank funding for protected area management in the mid-1990s, one of the first requirements of the program was that a repository of geographically referenced biological information be constructed. The National Herbarium and the forestry institute served as the basis for this work, which provided the botanical data and technical support for a national vegetation map (INEFAN 1996). The outcome of the World Bank's program was the creation of the Ministry of the Environment in 1996, which then had authority over the country's protected areas. The forestry institute, which had previously held these responsibilities, was moved from its longstanding home in the Ministry of Agriculture and Livestock. Whereas protected area management had been a sub-department of Ecuador's forestry authority in the 1970s, the reverse became true in the mid-1990s. Moreover, by the time the Ministry of the Environment was formed, a highly active field of environmental organizations already existed with which it would interface, which provided financing for the country's protected areas, and which could describe and track the environmental impacts of the country's most important economic sector. While the creation of Ecuador's Ministry of the Environment in 1996 usefully marks a degree of public interest in biodiversity loss, it was enabled by the already-existing field of taxonomic government. $^{20}$

Counter-intuitively, neoliberal reforms inadvertently contributed to the production of biodiversity in Ecuador. Scholars studying neoliberal reforms'impacts on natural resource management have emphasized the removal of state regulation and processes of commodification (Liverman \& Vilas, 2006; Yates \& Bakker, 2006). This scholarship has observed that neoliberal reforms have frequently privatized resources by "rolling back" existing state regulatory authority and "rolling out" state institutions designed to be dependent on the private sector (Peck \& Tickell, 2002). These are obviously crucial aspects of neoliberalism. Yet, in Ecuador's case a narrow focus on commodification as these scholars conceive it, rather than reflexive processes of economization, would miss the emergence of a historically distinct relationship to resources at precisely the time when the state was most susceptible to reorientation (Ong \& Collier, 2005). The "rolling out" of a Ministry of the Environment reliant on consultants, NGOs and bilateral aid had less to do with privatizing formerly publicly held resources than a reorientation of the state that resulted from linking it to a novel calculative apparatus.

Callon \& Muniesa (2005) suggest that one way of thinking about political power is in terms of the asymmetry in calculative capacities between devices. A drastic asymmetry existed between the Ecuadorian state and the distributed qualifying apparatus predicated on biological practices described here. The latter was able to map the space of the territorial nation-state in biological terms, and even calculate the impacts of foreign oil companies. Setting aside preconceptions about the "decentralized" character of institutional arrangements that emerged from neoliberal reforms, the technology of spatial prioritization founded by the National Herbarium in fact appears highly centralized: it was premised on close coordination of agencies and their mandates through shared protocols, methods and personnel under a single fiscal authority. The centralized character of this apparatus was a function of the kind of political program it sought to enact, in which fine-grained biological information would eventually inform natural resource governance. An analysis of governmentality - a focus on the uptake of specific rationales (in particular, the spatial logic of resource-making) and practices (in particular, biological inventory and taxonomically-based systematics) - helps to clarify these political arrangements in a way that a focus on alliances and confrontations between institutions of different national origins, between state and civil society, or between different arms of the state, would not. The National Herbarium and its sibling institutions did not confront the Ecuadorian state as external entities, and neither were 
they situated neatly within it. They transected the state, provisioning it at different locations with biological data for which it had little regulatory use until 1996. The spatial distribution of biological resources became a conventionalized basis for environmental management as this apparatus became an increasingly relied-upon infrastructure of state regulation. Biodiversity was thus instituted.

\section{Conclusion: Performing the "Little Science" of Biological Systematics}

In describing the role of the accounting technique of double-entry bookkeeping in the rise of capitalism, Callon \& Muniesa (2005) note that it did not simply solve a problem that was clearly outlined in advance. Rather, double-entry bookkeeping reconfigured how profits were conceived and calculated as it became institutionalized: "We could even say that [double-entry bookkeeping], simply by being there, available, proposes this calculation to the entrepreneur who accepts the invitation" (Callon \& Muniesa, 2005: 17). A similar phenomenon occurred with the techniques and infrastructures that assembled taxonomic government from the mid-1980s to the mid-1990s. Botany was a particularly important discipline for this work because of its use in characterizing territory. The National Herbarium and its sibling institutions formed a distributed qualifying device able to link space and plant resources through biological systematics. Botanical practices were taken up and transformed in the oil field to produce petroleum sites as objects for floristic inventory, helping to define the terms in which state regulation would be enacted. Calculative capacities were repeatedly proposed, and the invitation to configure territory and plant resources through them was repeatedly accepted. Taxonomic government evolved as biologists' practices assumed a central role in territorial management and development planning in public institutions, NGOs, environmental consultancies and oil companies.

Studies of knowledge infrastructure routinely emphasize its coordinating function: knowledge infrastructure has, built into it, particular modes of interaction between communities of experts (Bowker, 1994; Star \& Bowker, 2010). An analytic of governmentality, as deployed here, can shed light on the political ramifications of such infrastructure work by tracing the rationales and practices of experts across institutional boundaries as these cohere into enduring and powerful paradigms for the conduct of conduct (Foucault, 2007). Examined in this light, knowledge infrastructure work exhibits many of the problems of large-scale social coordination and the deployment of expert knowledge associated with modern political institutions. Biodiversity conservation arrived in Ecuador as a form of planned economic change predicated on the qualification of territory. Attending to the infrastructure work involved in instituting biodiversity shows how future biodiversity conservation was anticipated and staged (Star \& Bowker, 2010) - not just the "conduct of conduct", but the "planning of planning". To the extent that biodiversity came to exist as a formally recognizable value in Ecuador, it did so because of the way that biologists' practices formed the foundation for a field of environmental work.

While the primary focus of this article has not been on the contemporary implications of taxonomic government, Yasuní National Park is once again informative in this regard. The National Herbarium's work on Amazonian floristics in the 1990s has allowed plant ecologists to link Yasuní to international ecological research (Losos \& Leigh, 2004). Its embeddedness in these networks has resulted in greater international outcry from experts about the threats posed by development in previously unexploited portions of the park (Bass et al., 2010; Finer et al., 2009). The outcry, in turn, has prompted an increased level of scrutiny at the national level, making Yasuní the target of a huge number of environmental studies in anticipation of the infrastructure required to produce oil and move it to refineries. Thus, we can see the performativity of biodiversity infrastructure work (Bowker, 2000b): positing a region as biodiverse results in a spiral of increasing biological information about it. This cycle of knowledge production has been enabled and amplified by petroleum development. Yasuní has emerged as both a thoroughly exploited oil field, and a well-documented tropical rainforest valued for its biodiversity.

The contemporary environmental consulting industry in Ecuador manifests a less intuitive 
performative aspect of this history. Advocates for biodiversity, such as E. O. Wilson and Peter Raven, treated biological systematics as the base on which biodiversity conservation needed to be built in the 1990s. The "little science" was subsequently "infrastructured" for this purpose into a field of environmental actors, including the Ecuadorian state. The relatively prestigious work of international botanical exploration has moved on to areas of South America that are less "wellcollected", as the National Herbarium's research resulted in the Ecuadorian Amazon being one of the best-studied parts of the watershed. Biological systematics has been reworked into a "gray science" (Rose et al., 2006) or "little tool" (Asdal, 2008b) most often used in environmental impact studies. The resulting apparatus makes it possible to qualify Yasunís petroleum sites in terms of individuated biotic constituents. At the same time, while ecologists have played a highly visible role in environmental advocacy around Yasuní, a common complaint of environmental consultants is that ecological knowledge is not well-integrated into the environmental impact studies that govern oil development. The overwhelming historical focus on biological inventory in the country has made it difficult to trace connections between society and environment in the fashion typical of "biopolitics", or government of the systems that ensure the vitality of populations and individuals (Foucault, 2008; Olson, 2010). Hampered in their ability to draw these connections, contemporary environmental consulting studies of Yasuní could be considered "pre-biopolitical".

The present oil development in Yasuní has garnered attention partially because it highlights controversial changes in Ecuador's own environmental regulatory apparatus. In the last decade, the administration of President Rafael Correa has enacted restrictions on the foreign financing that previously supported environmental NGOs; scaled back public consultation in the develop- ment process; and maintained a hostile posture toward the field of environmental activism. In effect, these policies have dismantled portions of the apparatus described in this article. Scholars have asked what the "post-neoliberal" era (Yates \& Bakker, 2013) means for rights and resources in Ecuador and Latin America, generally. The case of Yasuní shows that biodiversity cannot be blithely disregarded, but the conditions in which it will be governed continue to evolve. Whether these emergent arrangements are later deemed neoliberal, "post-neoliberal" or something else, understanding them will require carefully tracing the mutations of institutions and techniques that generate and respond to the problems of government.

\section{Acknowledgements}

I extend my thanks to the numerous Ecuadorian and American botanists who have shared their time and expertise with me in the course of my research. I especially thank Diana Fernandez, the staff of the National Herbarium, and David Neill for their openness and patience with this research. Portions of this article would not have been possible without access to David Neill's archive and his vivid personal recollections, for which I am extremely grateful. Brian Silverstein, Tom Sheridan, Juliet Erazo, and Valerie Olson all provided exceedingly helpful comments on this work. The article also benefitted from feedback from Samantha Grace, Dana Osborne, Lucero Radonic, Sarah Raskin, and Audrey Jones. Finally, I thank the anonymous reviewers of a previous draft, whose thoughtful comments helped me to sharpen my argument. The research was conducted with financial support from Wenner-Gren Dissertation Fieldwork Grant \#8504 and a Dissertation Research Grant from the University of Arizona's Social and Behavioral Sciences Research Institute. 


\section{References}

Acosta A (2010) Las Tribulaciones de la Iniciativa Yasuní-ITT. Letras Verdes 5: 19-22.

Acosta-Solís M (1944) Algunas Consideraciones sobre la Tierra Ecuatoriana y Su Colonizacion; La Necesidad de Colonizar las Areas Comprendidas Entre Santo Domingo y Esmeraldas; Principales Productos Vegetales de Porvenir Económico que Deben Intensificarse en el Trópico Noroeste Ecuatoriano. Quito: Instituto Ecuatoriano de Ciencias Naturales.

Asdal K (2008a) Enacting Things Through Numbers: Taking Nature Into Account/ing. Geoforum 39: 123-32.

Asdal K (2008b) On Politics and the Little Tools of Democracy: A Down-to-Earth Approach. Distinktion: Scandinavian Journal of Social Theory 9(1): 11-26.

Bass M, Finer M, Jenkins C, Kreft H, Diego F, McCracken S, Pitman N, English P, Swing K, Villa G, Di Fiore A, Voigt C, \& Kunz T (2010) Global Conservation Significance of Ecuador's Yasuní National Park. PLos ONE 5(1): $1-22$.

Bowker G (1994) Science on the Run: Information Management and Industrial Geophysics at Schlumberger, 1920-1940. Cambridge, MA: MIT Press.

Bowker G (2000a) Biodiversity Datadiversity. Social Studies of Science 30(5): 643-83.

Bowker G (2000b) Mapping Biodiversity. International Journal of Geographical Information Science 13: 739-754.

Bowker G (2005) Time, Money and Biodiversity. In: Ong A \& Collier SJ (eds) (2005) Global Assemblages: Technology, Politics, and Ethics as Anthropological Problems. Malden, MA: Blackwell.

Bowker G \& Star SL (2000) Sorting Things Out: Classification and its Consequences. Cambridge, MA: MIT Press.

Brogden M \& Greenberg J (2003) The Fight for the West: A Political Ecology of Land Use Conflicts in Arizona. Human Organization 62(3): 289-298.

Burchell G, Gordon C \& Miller P (1991) The Foucault Effect: Studies in Governmentality. Chicago, IL: University of Chicago Press.

Çalişkan K \& Callon M (2009) Economization, Part 1: Shifting Attention from the Economy Towards Processes of Economization. Economy and Society 38(3): 369-398.

Çalişkan K \& Callon M (2010) Economization, Part 2: A Research Programme for the Study of Markets. Economy and Society 39(1): 1-32.

Callon M (1998) An Essay on Framing and Overflowing: Economic Externalities Revisited by Sociology. The Sociological Review 46(S1): 244-269.

Callon M, Méadel C \& Rabeharisoa V (2002) The Economy of Qualities. Economy and Society 31(2): $194-217$.

Callon M \& Muniesa F (2005) Economic Markets as Calculative Collective Devices. Organization Studies 26(8): $1229-1250$.

Callon M, Yuval M \& Muniesa F (2007) Market Devices. Malden, MA: Blackwell.

Central Intelligence Agency (1998) World Factbook. Washington D.C.

Cochoy F (2008) Calculation, Qualculation, Calqulation: Shopping Cart Arithmetic, Equipped Cognition and the Clustered Consumer. Marketing Theory 8(1): 15-44.

Collier SJ (2011) Post-Soviet Social: Neoliberalism, Social Modernity, Biopolitics. Princeton, NJ: Princeton University Press.

Conservation Data Center (no date) Work strategy for botany (Estrategia de trabajo del area de botánica). Unpublished report. 
Conservation Data Center (1990) General Report of the Conservation Data Center (Informe general del CDC). Unpublished report.

Cuvi N (2005) La Institucionalización del Conservacionismo en el Ecuador (1949-1953): Misael Acosta-Solís y el Departamento Forestal. Procesos: Revista Ecuatoriana de Historia 22: 107-129.

Cuvi N (2009) Las Semillas del Imperialismo Agrícola Estadounidense en el Ecuador. Revista Ecuatoriana de Historia 30(2): 69-98

Cuvi N (2011) The Cinchona Program (1940-1945): Science and Imperialism in the Exploitation of a Medicinal Plant. Dynamis 31(1): 183-206.

Dinerstein E, Olson DM, Graham DJ, Webster AL, Primm SA, Bookbinder MP, Ledec G, \& World Wildlife Fund (1995) A Conservation Assessment of the Terrestrial Ecoregions of Latin American and the Caribbean. Washington D.C.: World Bank.

Dodson CH \& Gentry AH (1978) Flora of the Rio Palenque Science Center, Los Rios Province, Ecuador. Selbyana 4(1-6): 1-628.

Dodson CH \& Gentry AH (1991) Biological Extinction in Western Ecuador. Annals of the Missouri Botanical Garden 78(2): 273-295.

Donzelot J (1997) The Policing of Families. Baltimore, MD: Johns Hopkins University Press.

Erazo J (2013) Governing Indigenous Territories: Enacting Sovereignty in the Ecuadorian Amazon. Durham, NC: Duke University Press.

Fairhead J \& Leach M (2003) Science, Society and Power: Environmental Knowledge and Policy in West Africa and the Caribbean. New York: Cambridge University Press.

Finer M, Vijay V, Ponce F, Jenkins CN, \& Kahn TR (2009) Ecuador's Yasuní Biosphere Reserve: A Brief Modern History and Conservation Challenges. Environmental Research Letters 4(3): 1-15.

Foucault M (2007) Security, Territory, Population: Lectures at the Collège de France, 1977-78. London: PalgraveMacmillan.

Foucault M (2008) The Birth of Biopolitics: Lectures at the Collège de France, 1978-79. London: PalgraveMacmillan.

Grove, Richard (1996) Green Imperialism: Colonial Expansion, Tropical Island Edens and the Origins of Environmentalism, 1600-1860. Cambridge, UK: Cambridge University Press.

Guy D \& Sheridan T (1998) On Frontiers: The Northern and Southern Edges of the Spanish Empire in the Americas. In: Guy D \& Sheridan T (eds) Contested Ground: Comparative Frontiers on the Northern and Southern Edges of the Spanish Empire. Tucson, AZ: University of Arizona Press, 3-15.

Hayden C (2003) When Nature Goes Public: The Making and Unmaking of Bioprospecting in Mexico. Princeton, NJ: University of Princeton Press.

Hey JAK \& Klak T (1999) From Protectionism Towards Neoliberalism: Ecuador Across Four Administrations (1981-1996). Studies in Comparative International Development 34(3): 66-97.

INEFAN (1996) Interinstitutional Agreement for the Transfer of Taxonomic Information (Convenio Interinstitucional para Traspaso de Información Taxonómica). Institutional agreement with National Herbarium, April 1996.

Jácome H LI (2004) The Late 1990s Financial Crisis in Ecuador: Institutional Weaknesses, Fiscal Rigidities, and Financial Dollarization at Work. IMF Working Paper 4/12. Washington D.C.: International Monetary Fund, January.

Jasanoff S (2013) Science and Public Reason. New York: Routledge. 
Jay S, Jones C, Slinn P \& Wood C (2007) Environmental Impact Assessment: Retrospect and Prospect. Environmental Impact Assessment Review 27(4): 287-300.

Karasti H, Baker KS \& Millerand F (2010) Infrastructure Time: Long-Term Matters in Collaborative Development. Computer Supported Cooperative Work 19: 377-415.

Kimerling J (1990) Disregarding Environmental Law: Petroleum Development in Protected Natural Areas and Indigenous Homelands in the Ecuadorian Amazon. Hastings International and Comparative Law Review 14: 849-903.

Kimerling J (1995) Rights, Responsibilities, and Realities: Environmental Protection Law in Ecuador's Amazon Oil Fields. Southwest Journal of Law and Trade in the Americas 2: 293-303.

Klawiter M (2008) The Biopolitics of Breast Cancer: Changing Cultures of Disease and Activism. Minneapolis, $\mathrm{MN}$ : University of Minneapolis Press.

Kohler RE (2006) All Creatures: Naturalists, Collectors and Biodiversity, 1850-1950. Princeton, NJ: Princeton University Press.

Li TM (2007) The Will to Improve: Governmentality, Development and the Practice of Politics. Durham, NC: Duke University Press.

Liverman D \& Vilas S (2006) Neoliberalism and the Environment in Latin America. Annual Review of Environment and Resources 31: 327-363.

Losos EC and Leigh, Jr. EG (eds) (2004) Tropical Forest Diversity and Dynamics: Findings From a Large-Scale Plot Network. Chicago, IL: University of Chicago Press.

Lowe C (2006) Wild Profusion: Biodiversity Conservation in an Indonesian Archipelago. Princeton, NJ: Princeton University Press.

MacKenzie D, Muniesa F, \& Siu L (2008) Do Economists Make Markets?: On the Performativity of Economics. Princeton, NJ: Princeton University Press.

Mathews AS (2011) Instituting Nature: Authority, Expertise and Power in Mexican Forests. Cambridge, MA: MIT Press.

McCook S (2002) States of Nature: Science, Agriculture and Environment in the Spanish Caribbean, 1760-1940. Austin, TX: University of Texas Press.

Miller C (2001) Gifford Pinchot and the Making of Modern Environmentalism. Washington D.C.: Island Press.

Miller P \& Rose N (1997) Mobilizing the Consumer: Assembling the Subject of Consumption. Theory, Culture and Society 14: 1-36.

Mitchell T (2003) The Rule of Experts: Egypt, Techno-politics, Modernity. Berkeley, CA: University of California Press.

Müeller-Wille S \& Scharf S (2009) Indexing nature: Carl Linnaeus (1707-1778) and his Fact-Gathering Strategies. Working Papers on The Nature of Evidence: How Well Do 'Facts' Travel? 36/08. London: London School of Economics, January.

Nading AM (2012) Dengue Mosquitoes are Single Mothers: Biopolitics Meets Ecological Aesthetics in Nicaraguan Community Health Work. Cultural Anthropology 27(4): 572-596.

Neill, David (1985) Plant Resources of Amazonian Ecuador ("Flora del Ecuador"), Third Project Report (AugustDecember 1985). Draft report to USAID, 1985.

Neill, David (1990). Botanical Inventory of the Petro-Canada Road, Rio Tigüino, and the Cachiyacu and Golondrina Well Sites, Pastaza Province, Ecuador. Consultant's report to Petro-Canada, 1990.

Neill D, Clark JL, Vargas H \& Nuñez T (1999) Botanical Exploration of the Maché-Chindul Mountains, Northwestern Ecuador. Final report to the National Science Foundation, March 1999. 
Olson V (2010) The Ecobiopolitics of Space Biomedicine. Medical Anthropology: Cross-Cultural Studies in Health and IIIness 29(2): 170-193.

Ong A \& Collier SJ (eds) (2005) Global Assemblages: Technology, Politics, and Ethics as Anthropological Problems. Malden, MA: Blackwell.

Pearson DL, Crump ML, Emmons LH, Foster RB (1978) Final Report on the Biological Study of the Yasuní River (Reporte final sobre el estudio biológico del Rio Yasuní). Consultants' report to World Wildlife Foundation, May 1978.

Peck J \& Tickell G (2002) Neoliberalizing Space. Antipode 34(3): 380-404.

Power M (1999) The Audit Society: Rituals of Verification. New York: Oxford University Press.

Power M (2004) Counting, Control and Calculation: Reflections on Measuring and Management. Human Relations 57(6): 765-783.

Rabinow P (2003) Essays on the Anthropology of Reason. Princeton, NJ: Princeton University Press.

Rabinow P \& Rose N (2006) Biopower Today. Biosocieties 1(2): 195-217.

Raffles H (2002) In Amazonia: A Natural History. Princeton, NJ: Princeton University Press.

Raven PH \& Wilson EO (1992) A Fifty-Year Plan for Biodiversity Surveys. Science 258(5085): 1099-1100.

Renner SS (1993) A History of Botanical Exploration in Amazonian Ecuador, 1739-1988. Smithsonian Contributions to Botany No. 52. Washington D.C.: The Smithsonian Institute.

Rival L (2010) Ecuador's Yasuni-ITT Initiative: The Old and New Values of Petroleum. Ecological Economics 70: 358-365.

Rival L (2011) Planning Development Futures in the Ecuadorian Amazon: The Expanding Oil Frontier and the Yasuni-ITT Initiative. In Bebbington A (ed) Social Conflict, Economic Development and Extractive Industry: Evidence from South America. London: Routledge, 153-171.

Rose N (1999) Power of Freedom: Reframing Political Thought. Cambridge, UK: Cambridge University Press.

Rose N, O'Malley P \& Valverde M (2006) Governmentality. Annual Review of Law and Social Science 2: 83-104.

Sadler R (1990) Debt-for-Nature Swaps: Assessing the Future. Journal of Contemporary Health Law and Policy 6(1): 319-41.

Schulenberg TS \& Awbrey K (1998) The Cordillera del Cóndor Region of Ecuador and Peru: A Biological Assessment. RAP Working Papers 7. Washington D.C.: Conservation International, January 1997.

Sevilla E \& Sevilla A (2013) Inserción y Participación en las Redes Globales de Producción de Conocimiento: El Caso del Ecuador del Siglo XIX. Revista Historia Crítica 50: 79-103.

Sevilla Pérez AM (2013) El Ecuador en Sus Mapas: Estado y Nación Desde una Perspectiva Espacial. Quito: Facultad Latinoamericana de Ciencias Sociales.

Sheridan T (2007) Embattled Ranchers, Endangered Species, and Urban Sprawl: The Political Ecology of the New American West. Annual Review of Anthropology 36: 121-138.

Silverstein B (2015) Statistics, Reform and Regimes of Expertise in Turkey. Turkish Studies 15(4): 638-54.

Spence MD (2000) Dispossessing the Wilderness: Indian Removal and the Making of the National Parks. New York: Oxford University Press.

Star SL (2010) This is Not a Boundary Object: Reflections on the Origin of a Concept. Science, Technology and Human Values 35: 601-617.

Star SL \& Bowker G (2010) How to Infrastructure. In: Lievrouw LA \& Livingstone S (eds) Handbook of New Media. London: Sage Publications, 230-246. 
Striffler S (2001) In the Shadows of State and Capital: The United Fruit Company, Popular Struggle and Agrarian Restructuring in Ecuador, 1900-1995. Durham, NC: Duke University Press.

Takacs D (1996) The Idea of Biodiversity: Philosophies of Paradise. Baltimore, MD: Johns Hopkins University Press.

Tucker RP (2011) A Forest History of India. Thousand Oaks, CA: Sage.

Ulloa UC \& Neill D (2006) Phainantha shuariorum (Melastomataceae), una Especie Nueva de la Cordillera del Cóndor, Ecuador, Disyunta de un Genero Guayanés. Novon 16(2): 281-285.

UNDP-FAO (1974) Management and Integrated Development of Wild Areas (Manejo y Desarrollo Integral de Areas Silvestres), Technical document No. 4, 1974.

UNDP-FAO (1976) Final Report: Preliminary Strategy for the Conservation of Outstanding Wild Areas of Ecuador (Informe final: Estrategia preliminar para la conservación de áreas silvestres sobresalientes del Ecuador). Consultants' report to Government of Ecuador, February 1976.

U.S. National Park Service (1974) National Park System Plan (Natural History) for Greece, Consultants' Report to the OECD, 1974.

Vandergeest P \& Peluso N (1995) Territorialization and State Power in Thailand. Theory and Society 24(3): 385-426.

Weber M (1978) Economy and Society, Volume 1. Berkeley, CA: University of California Press.

Wilson EO \& Peter FM (eds) (1988) Biodiversity. Washington D.C.: National Academy Press.

Yates JS \& Bakker K (2013) Debating the "Post-Neoliberal Turn" in Latin America. Progress in Human Geography 38(1): 62-90.

\section{Notes}

1 Eighty percent of the historical documentation examined during this article's writing, and all archival documents cited, come from the personal archive of David Neill. Approximately $15 \%$ of the documents examined come from the libraries of two environmental consultancies and the remaining $5 \%$ from the archives of the National Herbarium. These resources were augmented by interviews with 31 individuals dealing with the history of the National Herbarium, environmental consulting and botany in the country. This included individuals presently or previously affiliated with the National Herbarium, Missouri Botanical Garden, the Pontifical Catholic University in Quito, Aarhus University in Denmark, the Ministry of the Environment, and private consultancies.

2 Rapid informal settlement of Ecuador's "internal frontiers" was a result of radical inequality in land tenure (Hey \& Klak, 1999). The practice was bolstered by the legal doctrine, shared by former Spanish colonies, of tierras baldías. This doctrine framed uncultivated, and especially forested land as economically unproductive (Guy \& Sheridan, 1998). In Ecuador, legal title to land could be acquired by clearing it of forest to demonstrate the intention to use land productively. National policies encouraging settlement were seen as politically expedient alternatives to the sensitive task of redistributing the land holdings of the country's agricultural elites.

3 Taxonomic government, as defined here, is not best conceived as a form of what Foucault termed "biopower". Rabinow \& Rose (2006) define biopower in terms of political rationalities and interventions centered upon the "vitality" of individuals and collectivities. For the thinkers and disciplines that Foucault studied, and those analyzed in the literature he has inspired, "vitality" has been understood to be a function of self-maintaining, reproducing, or teleological systems with different inflections across such disciplines as economics (Collier, 2011), ecology (Nading, 2012) or medicine (Klawiter, 2008). On the other hand, systematic biology is not primarily concerned with self-regulating systems; rather, it names objects and situates them in terms of evolutionary relatedness to other known and named 
objects - a very different notion of "system". Ecology and population biology were integrated into the programs of NGOs working in the country in the late 1990s and 2000s, and played roles in community-level interventions focused on the reform of human-environment relationships. Importantly, taxonomic government as analyzed here was primarily focused on intervening upon formal organizations, rather than at the level of communities, in order to configure biodiversity as an actionable political problem. Its central features, biological inventory and taxonomic systematics, continue to be central in environmental consulting and state-level planning.

4 A distinction intended to parallel Weber's (1978) between substantive and formal rationality.

5 USAID memorandum to MOBOT regarding Flora of Ecuador grant extension, 12.3.1985.

6 Because of the historical reliance on foreign technical assistance in forestry and agronomy, many of their technical products (including specimens) ended up exclusively in foreign hands. This was one of the reasons that MOBOT needed to create a herbarium in Ecuador at the outset of its work.

$7 \quad$ Ecuador's existing forestry research had links to the U.S. tradition of conservation through the sustainable management of resources associated with the USDA and U.S. Forest Service (Miller, 2001). On the other hand, protected area planning borrowed directly from the U.S. National Park System (Spence, 2000). Each of these traditions was picked up and modified in the Ecuadorian context (e.g. Cuvi, 2005).

8 Ecuador's National Herbarium was formally created as a subsection of the Museum of Natural Sciences by the Danish botanist Lauritz Holm-Nielsen when he registered its acronym (QCNE) with the New York Botanical Garden's Index Herbariorum in 1977. However, the Herbarium existed only on paper until the period discussed here, when an agreement was reached to allow MOBOT field collectors to grow and manage its collection, again under the supervision of the Museum. The collaboration between Danish botanists based at the University of Aarhus, and botanists and the Pontifical Catholic University in Quito was the other major botanical program in the country at this time. Botanists from this collaboration also worked with the National Herbarium on some of its consulting work in the 1990s, as well as other projects.

9 Letter from Alwyn Gentry to Peter Raven concerning TNC program, 8.5.1986.

10 "Ecoregion" was a scale of planning used elsewhere in conservation during this period (e.g. Dinerstein et al., 1995).

11 A small subset of these remains available online at http://botany.si.edu/projects/cpd/samap.htm.

12 This initial contact was with a U.S. contractor working for the Corporación Estatal Petrolera Ecuatoriana, the state oil company that became Petroecuador in 1989, shortly thereafter.

13 Petroleum was the country's largest contributor to GDP and provided roughly half of all state revenue (CIA, 1998). Much like forestry, oil operations relied extensively on the technical support of foreign companies. The primary form of regulation for petroleum for much of the $20^{\text {th }}$ century was risk-sharing agreements between the Ecuadorian state and foreign oil developers that were widely considered to be unfavorable to the country. This unregulated development resulted in a well-publicized international lawsuit, brought in 1993 against Texaco (later bought by Chevron) for its socially and environmentally destructive operating practices during the 1970s and 1980s (Kimmerling, 1990, 1995). The legacy of Texaco's work provided a highly public example of what "the worst of the worst" foreign petroleum operators were capable of, in the words of some consultants interviewed for this research.

14 While summarizing the National Herbarium's negotiations with Conoco in a memorandum to Peter Raven, David Neill wrote "[An environmental advisor at USAID] said that he tried to emphasize to the Conoco people that they could do something here that would be very beneficial and be of great propaganda value for the company, for a relatively low cost (much less than paying lawyers in a lawsuit 5-10 years from now), and evidently he convinced them" (memo concerning contract negotiations with 
Conoco, 3.22.1988). Raven was also in contact with Conoco's environmental office in Houston, which he described as enthusiastically supportive of the consulting arrangement with the National Herbarium (memo from Peter Raven to David Neill concerning Conoco contract negotiations, 8.30.1988).

15 A "collection" is a group of specimens that come from the same individual plant and are identified by a single collection number. When an expert identifies a duplicate from a collection, the other specimens from that collection are effectively identified, as well. Individual specimens from the same collection can be shared between institutions, allowing different herbaria to have taxonomically identified specimens from the same plant.

16 David Neill, Botanical Inventory and Revegetation of the Maxus Pipeline Road, Petroleum Block 16, Amazonian Ecuador. Maxus service contract, 5.1.1994. Renner mentioned and explicitly omitted the National Herbarium's ongoing oilfield collecting from her calculations in 1993.

17 These changes roughly parallel the shifting roles of biology and ecology in the U.S. with the implementation of the National Environmental Protection Act in 1969, and the consequent rise of the environmental consulting industry there (Jay et al., 2007).

18 With the plummeting value of the sucre against the dollar in the 1990s, MOBOT enjoyed a roughly 6:1 return on an initial purchase of $\$ 50,000$ worth of debt, financing much of the National Herbarium's herbarium activity from 1989 through roughly 1997 with an eventual equivalent of about $\$ 350,000$ at 1989 exchange rates. These approximations are based on David Neill's recollections and an examination of partial records of the National Herbarium's budgets in the early 1990s. This was a small component of a larger USD3.5 million deal for developing the country's system of protected areas.

19 The Conservation Data Center was operated with a similarly complex arrangement, once again answering to Fundación Natura for financial accountability.

20 Another indication of the broad international interest in biodiversity was the Convention on Biological Diversity, of which Ecuador was a signatory in 1992. 